\title{
Background for studies on the treatment of male osteoporosis: state of the art
}

\author{
J M Kaufman, O Johnell, E Abadie, S Adami, M Audran, B Avouac, W Ben Sedrine, \\ G Calvo, J P Devogelaer, V Fuchs, G Kreutz, P Nilsson, H Pols, J Ringe, L Van Haelst, \\ J Y Reginster $\star$
}

\begin{abstract}
Male osteoporosis represents an important, although long underestimated, public health problem. Both in men and in women aging is accompanied by continuous bone loss and by an exponential increase in the incidence of osteoporotic fracture, with a female to male incidence ratio of about 2 to 3 to 1 in the elderly for hip and vertebral fractures. Morbidity after osteoporotic fractures appears to be more serious and mortality more common in men than in women. To date, no single treatment has been proved to be effective and safe in published prospective studies.
\end{abstract}

The present report, based on a systematic search of the literature on male osteoporosis, summarises the state of the art on the clinical consequences of male osteoporosis and its risk factors, in relation to the present state of knowledge about female osteoporosis. This constitutes the background for the design of rational clinical development strategies for therapeutic interventions in male osteoporosis. From this review of the literature it is apparent that notwithstanding the existing sex differences in pathophysiology of osteoporosis and the difference in age-specific incidence of osteoporotic fractures, there are also important similarities between osteoporosis in women and men. The higher incidence of fracture in women than in men results from quantitative differences in risk factors rather than from different risk factors. Even though there are sex differences in bone geometry, incidence of fracture seems to be similar in men and women for a same absolute areal bone mineral density. However, the lack of data on the changes in fracture rates in men resulting from pharmacological intervention, leading to changes in bone mineral density or bone turnover, remains the main limitation for extrapolation of established treatment outcomes from women to men.

(Ann Rheum Dis 2000;59:765-772)
Osteoporosis has long been considered a disease of women. More recently, there has been increasing recognition that osteoporotic fractures in men also represent an important public health problem. ${ }^{1-4}$

To date, published prospective studies have not adequately proved any single treatment to be effective and safe. Nevertheless, recently, useful information has been obtained on the epidemiology of male osteoporotic fractures and their relation to risk factors such as bone mineral density. Several large scale prospective observational studies including both men and women are presently being conducted, such as the Rotterdam study, ${ }^{5}$ the Malmö study, ${ }^{6}$ and the Dubbo study. ${ }^{7}$

The present document is based on a systematic search of the literature on male osteoporosis complemented, when appropriate, by relevant recent data published in abstract form. It aims at summarising the state of the art on the clinical consequences of male osteoporosis and its risk factors, in relation to the present state of knowledge about female osteoporosis. This constitutes the background for the design of rational clinical development strategies for therapeutic interventions in male osteoporosis. Such strategies should take sufficiently into account the particularities of male osteoporosis while taking advantage, whenever possible, of the considerable recent progress achieved in the treatment of female osteoporosis.

\section{The burden of illness}

INCIDENCE OF HIP FRACTURES IN MEN

An age related increase in the incidence of hip fracture is found in both men and women, with a female to male incidence ratio of about 2 to 3 to 1 in the elderly. In fact, the hip fracture incidence in men reaches the same level as in women, at an age about 5 to 6 years older with, for instance, 80 year old men having the same hip fracture risk as 75 year old women. ${ }^{89}$ Numerous reports on the incidence of hip fracture in North America and different European countries have come to similar conclusions. ${ }^{10-18}$

The lifetime risk of hip fracture in men has been estimated as $6 \%$ compared with $17.5 \%$ in women. ${ }^{19}$ A recent lifetime risk estimate that takes into account the projected life expectancy of the male and female population, came to a
*Addresses given in the appendix. 
slightly higher estimation of the lifetime risk of hip fracture: $22.7 \%$ in women $v 11.1 \%$ in men at age $50 ; 20.0 \%$ in women $v 10.1 \%$ in men at age 80 . The difference in lifetime risk between men and women is explained by both a lower age-specific incidence and the shorter life expectancy in men. ${ }^{20}$

Two projections of the expected number of hip fractures world wide have been made. Cooper et al estimated the expected number of fractures to be 3.94 million in $2025,{ }^{21 a}$ of which 1.16 million are expected in men and 2.78 million in women. Gullberg et al estimated the number of fractures as 1.26 million (338 000 men and 917000 women) in $1990 .{ }^{22}$ If cyclical trends with increased age-specific incidence of hip fractures, which have been reported to be more pronounced in men than in women, are taken into account, the number of hip fractures might range between 7.3 and 21.3 millions by 2050; the percentage increase will be greater in men than in women. ${ }^{22}$

INCIDENCE OF VERTEBRAL FRACTURES IN MEN For vertebral fractures a clear distinction should be made between clinically diagnosed fractures and vertebral deformities. Information on clinical vertebral fractures in both sexes is limited. Cooper et al reported the age adjusted rate in women (145/100 000 personyears) to be almost twice that in men $(73 / 100.000 \text { person-years })^{21 b}$; similar observations have been made by Bengnér et al. ${ }^{23}$ As with the observation on hip fractures, there seems to be a 5 to 10 year age shift in the agespecific incidence of clinical vertebral fractures.

O'Neill et al have reported the prevalence of vertebral deformity in European men and women. ${ }^{24}$ Based on the McCloskey method, the mean centre prevalence of all deformities was $12 \%$ in women (range $6-21 \%$ ) and $12 \%$ in men (range 8-20\%). The prevalence increased with age in both sexes, though the gradient was steeper in women. There was, however, substantial geographical variation, with the highest rates in Scandinavian countries. The risk of vertebral deformity was greater in younger men than in women, possibly as a result of greater exposure to trauma during their working life, implying that these deformities probably should be considered as "traumatic". A similar overall prevalence of vertebral deformities in both sexes, with less progression to severe vertebral deformities in men, was reported by Burger et $a .^{25}$ Confirming the finding of the prevalence studies, figures on the prospectively assessed true incidence of vertebral deformities have recently been reported ${ }^{26}: 1.00$ (95\% confidence interval (CI) 0.84 to 1.19 ) woman and 0.56 (0.46 to 0.73 ) men had an incident deformity per 100 years' follow up.

INCIDENCE OF OTHER FRACTURE TYPES IN MEN A much larger difference in sex-specific incidence has been reported for the incidence of wrist fracture, ${ }^{6}$ with up to a fourfold difference.

The overall incidence of symptomatic fractures (all types confounded) in elderly men and women was evaluated in the Dubbo osteoporo- sis epidemiology study. ${ }^{27}$ An overall fracture incidence of 2685/100 000 person-years was found to correspond to an incidence of 1940/100 000 and 3250/100 000 in men and women, respectively. Residual lifetime fracture risk in a person aged 60 with average life expectancy was estimated to be $29 \%$ for men and $56 \%$ for women. Estimates of clinically apparent fracture rates, with the improved methodology in this study, were higher than those previously reported in both elderly men and women, with a marked preponderance of non-hip fractures in the $60-80$ year age group.

MORBIDITY AND MORTALITY AFTER

OSTEOPOROTIC FRACTURES

Several studies have estimated the one year mortality after hip fracture to be around 20\% in women and $30 \%$ in men. ${ }^{28}{ }^{29}$ All-cause mortality has also been reported to be higher in men than in women after vertebral fractures: 0.85 (95\% CI 0.71 to 0.96$)$ and 0.72 (95\% CI 0.51 to 0.93 ) for survival in women and men, respectively. ${ }^{30}$ In the Dubbo study mortality was found to be increased after all major types of osteoporotic fractures. ${ }^{31}$ Standardised mortality ratios were higher in men both for incident and prevalent clinically diagnosed vertebral fractures. In women the ratios were 1.6 (1.4 to 1.8) for incident and 1.8 (1.6 to 2.1) for prevalent vertebral fractures. In men, these ratios were 1.8 (1.6 to 2.0) and 3.7 (3.4 to 3.9); standardised mortality ratios were higher for men than women for all fracture types.

Little published information is available on differences in the quality of life between the sexes after osteoporotic fractures. However, in the EVOS study the associations between vertebral deformities and negative health outcomes were stronger in men than in women, ${ }^{32} 33$ though there may be regional differences, as suggested by an analysis of German subjects ${ }^{34}$; similar observations were made by Burger et $a l^{25}$ There have also been reports of higher rates of hospitalisation and institutionalisation after osteoporotic fractures in men than in women. ${ }^{35}$

\section{Risk factors for osteoporotic fractures in} men

Besides bone mineral density (BMD; see below) and age, which are major risk factors, several other independent risk factors for osteoporotic fractures in men have been identified. In the Dubbo study independent risk factors for osteoporotic fractures in a multivariate analysis, ${ }^{36}$ including $\mathrm{BMD}$, were quadriceps weakness (odds ratio $(\mathrm{OR})=1.43$ (1.18 to 1.73 ) per 10 kilogram) and higher body sway $(\mathrm{OR}=1.25(1.07$ to 1.45$)$ per $5.15 \mathrm{~cm})$. Other independent risk factors were falls in the previous 12 months, a history of fracture in the previous five years, a lower body weight, and lower body height; protective factors included the use of thiazides, higher physical activity, and moderate alcohol intake.

Nyquist and coworkers showed that the risk of any fracture increases by a factor of 1.7 for 1SD decrease in skinfold thickness, measured on the dorsum of the hand. ${ }^{37}$ In the NHANES 
I epidemiological follow up study for hip fracture in white men, ${ }^{38}$ the adjusted relative risk (RR) of hip fracture was significantly associated with presence of one or more chronic conditions ( $\mathrm{RR}=1.91$; $95 \% \mathrm{CI} 1.19$ to 3.06 ), $10 \%$ or more weight loss from maximum $(\mathrm{RR}=2.27 ; 1.13$ to 4.59$)$, and $1 \mathrm{SD}$ change in phalangeal bone density $(\mathrm{RR}=1.73 ; 1.11$ to 2.68).

Poor and coworkers found that after adjusting for age, obesity, and inactivity, disorders linked with secondary osteoporosis were associated with a twofold increase in the risk of hip fracture in men $(\mathrm{OR}=2.93 ; 1.3$ to 4.3$)$, while conditions linked with an increased risk of falling were associated with an almost sevenfold increase in risk $(\mathrm{OR}=6.9 ; 3.3$ to 14.8$) .{ }^{39}$ These factors together seem to account for about $72 \%$ of the hip fractures in men.

In a case-control study, Grisso et al found the following risk factors for a first hip fracture: low body mass ( $R R=3.8 ; 95 \%$ CI 2.3 to 6.4 for men in the lower quintile); premorbid leg dysfunction ( $R R=3.4 ; 2.1$ to 5.4$)$; use of cimetidine $(R R=2.5 ; 1.4$ to 4.6$)$; use of psychotropic drugs ( $R R=2.2 ; 1.4$ to 3.3$)$; smoking cigarettes or a pipe (independent of body mass); while previous physical activity was markedly protective. ${ }^{40}$ In a Japanese study the risk of hip fracture in a large cohort of men was increased by a low body mass index (BMI), regular alcohol intake, and prevalent fractures. ${ }^{41}$ In a large prospective study alcohol intake of more than 27 drinks a week, but not moderate alcohol intake, was associated with a significant risk for hip fracture ${ }^{42}$. The prevalence of falls in men aged over 65 is half that in women $(19 \% v$ $34 \%$ ), but no sex-specific factors predisposing to the differing incidence have yet been clearly identified. ${ }^{36} 40$

In the MEDOS study both men and women from southern Europe were studied. ${ }^{43}$ Significant risk factors for hip fracture in men by univariate analysis included low body mass index, low sunlight exposure, a low degree of physical activity, low consumption of milk and cheese, and a poor mental score. Comorbidity factors, including sleep disturbances, loss of weight, impaired mental status, and poor appetite, were also significant risk factors. Previous stroke with hemiplegia, prior fragility fractures, senile dementia, alcoholism, and gastrectomy were also associated with significant risk, whereas osteoarthrosis, nephrolithiasis, and myocardial infarction were associated with lower risks. Taking drugs was not associated with a difference in risk, apart from a protective effect with the use of analgetics, independent of co-existing osteoarthrosis, and an increased risk with the use of anti-epileptic agents. Of the potentially "reversible" risk factors, BMI, leisure exercise, exposure to sunlight, and consumption of tea, alcohol, and tobacco remained independent risk factors after multivariate analysis, accounting for $54 \%$ of hip fractures. Excluding BMI, $46 \%$ of fractures could be explained on the basis of the risk factors sought. Of the remaining factors, low exposure to sunlight and decreased physical activity accounted for the highest attributable risks ( $14 \%$ and $9 \%$, respectively). The use of risk factors to predict hip fractures had relatively low sensitivity and specificity $(59.6 \%$ and $61.0 \%$, respectively). It was concluded that lifestyle factors are associated with significant differences in the risk of hip fracture. Potentially modifiable risk factors, including a low degree of physical exercise and a low BMI, account for a large component of the total risk. ${ }^{43}$ In the MEDOS study the pattern of risk factors for hip fracture was similar in both sexes. ${ }^{44}$ In case-control studies, testosterone deficiency has been identified as a specific risk factor for hip fractures in men. ${ }^{45-47}$

Slight but significant declines in 25hydroxycholecalciferol and increases in parathyroid hormone have been linked to bone loss in aging men ${ }^{48-50}$ and hypovitaminosis D identified as a risk factor for hip fracture. ${ }^{47}$

It has been suggested that secondary causes of osteoporosis may more often play a part in symptomatic vertebral fractures in men than in women $\left(50 \%\right.$ v 35\%). ${ }^{51}$ Long term glucocorticoid use, hypogonadism, alcoholism, and transplantation are well established causes of secondary osteoporosis in men and there is also some evidence for a role of gastrointestinal disorders, hyperparathyroidism, hypercalciuria, thyrotoxicosis, immobilisation, and use of anticonvulsant drugs as minor causes of secondary osteoporosis in men. ${ }^{51}$

An Sp1 binding site polymorphism in the COLIA1 gene has been shown to predict osteoporotic fractures in both men and women $(\mathrm{RR}=2.04$ and 1.37 in men and women, respectively)..$^{52}$

\section{Role of sex hormone deficiency in age related bone loss in men}

The sex differences that underlie the lower incidence of osteoporotic fractures in men may include the greater accumulation of skeletal bone mass during growth and the larger bone size in men as well as a lesser propensity to fall in elderly men. The absence of a distinctive equivalent of the menopause, with its related increase of bone turnover and accelerated bone loss resulting from oestrogen withdrawal, presumably also has a significant role.

In men, as is the case in women, acquired sex steroid deficiency results in increased bone turnover and accelerated bone loss, ${ }^{53}{ }^{54}$ bone turnover being reduced by treatment with antiresorptive drugs. ${ }^{53}$ Aging in men is characterised by a progressive decline of free (or bioavailable) serum testosterone levels (by about $50 \%$ between the ages of 25 and 75) and a progressive decline of free (or bioavailable) oestradiol levels. ${ }^{55-57}$ Results of cross sectional studies on the role of serum testosterone as an independent determinant of bone mass in elderly men have not been unequivocal, ${ }^{58}$ yet several studies have reported a significant independent contribution of serum testosterone in the determination of cancellous ${ }^{59}$ or cortical bone mass, or both. ${ }^{60}{ }^{61}$ Bone turnover tends to increase both in elderly women and men, though is more pronounced in the former. ${ }^{5062}$

Interestingly, recent findings suggest that elderly women with lower serum oestrogen 
levels have lower bone density values and a higher prevalence of vertebral deformities, ${ }^{63}$ while several reports indicate that serum oestradiol may also be a determinant of bone turnover and bone density in elderly men. ${ }^{616264}$ Low oestradiol levels have also been reported in men with idiopathic osteoporosis. ${ }^{65}$ Both oestrogen resistance ${ }^{66}$ and aromatase deficiency ${ }^{67}$ have been associated with low bone density in men, and it has been proposed that oestrogen deficiency may be a common and relevant pathophysiological mechanism in female and male osteoporosis. ${ }^{68}$

Giving testosterone to adult men with acquired hypogonadism has been reported to reduce bone turnover and increase bone density, ${ }^{69}{ }^{70}$ but this needs to be confirmed in controlled trials. It has recently been reported that testosterone treatment in elderly men with moderately low serum testosterone may result in a modest increase of bone mineral density at several measurement sites. ${ }^{71-73}$ Oestrogen treatment has been noted to increase bone mass in a man with aromatase deficiency. ${ }^{67}$

\section{Rate of bone loss in men}

Overall, the rate of bone loss at cortical sites seems to be greater in women than in men, whereas the rate of trabecular bone loss is less clearly influenced by sex. Mazess et al observed almost identical rates of trabecular bone loss in both sexes. ${ }^{74}$ Data from longitudinal studies ${ }^{75-78}$ have consistently shown that the rate of cortical bone loss in men may be considerably more rapid $(0.5-1 \%$ a year) than estimated from cross sectional studies (0.1-0.3\% a year). ${ }^{74} 7980$ In the cross sectional Framingham Osteoporosis Study the rate of bone loss at the predominantly trabecular trochanter site was similar in men and women $(0.45 \%$ and $0.53 \%$ a year, respectively). ${ }^{79}$ In the longitudinal Dubbo study $^{7}$ a higher rate of bone loss at the femoral neck was found, with increased rate of bone loss in the more elderly and rather similar rates of bone loss in both sexes: $0.96 \%$ a year $(95 \%$ CI 0.64 to $1.28 \%$ ) in women and $0.82 \%$ a year $(0.52$ to $1.12 \%)$ in men. In the Rotterdam study the rate of bone loss, adjusted for age and body mass index, was 0.0025 and 0.0045 $\mathrm{g} / \mathrm{cm}^{2} / \mathrm{y}$ in men and women, respectively. ${ }^{81}$ Bone loss accelerated with age, as was seen more clearly in men than in women. Lower body mass index and cigarette smoking were associated with increased bone loss in both men and women. In men, higher calcium intake was associated with lower rates, and disability was associated with a tendency to higher rates of bone loss. Alcohol intake was inconsistently related to the rate of bone loss in both sexes.

It should, however, be pointed out that age related changes in bone mineral density are accompanied by some sex-specific changes in bone geometry, with a higher increase of the cross sectional area of bones with advancing age in men. ${ }^{82}{ }^{83}$ Nevertheless, in longitudinal follow up continuing subperiosteal expansion seems to be similar in both sexes. ${ }^{84}$

Not only the cross sectional area of long bones but also the size of the vertebral bodies is clearly larger (by 25\%) in men than in women..$^{85}$ Prevalent areal BMD in adult men is higher than in adult women. However, sex differences in bone density are usually no longer apparent when volumetric densities are being considered. ${ }^{86}$ Owing to the sex differences in areal BMD, the prevalence of osteoporosis according to the proposed diagnostic categories of the WHO (World Health Organisation; ${ }^{87}$ ) will be different between the sexes. ${ }^{88}$

\section{Relation between prevalent bone mineral} density and fracture risk in men

A working party of the WHO has formulated proposals for diagnostic categories in osteoporosis $^{87}$ based on the relation between BMD (expressed as a T score - that is, BMD of the subject expressed as units of SD difference from the mean BMD in young adults) and the prospectively evaluated fracture risk. However, these proposals of the WHO working party apply only to white postmenopausal women.

Recently, prospective data on the relation between areal BMD and fracture risk in men became available. Gärdsell et al reported that bone mineral content at the forearm corrected for bone width is predictive of future fragility fractures. ${ }^{89}$ Other significant risk factors in this study were falls, lower grip strength, and lower body weight, as well as a history of previous vertebral fracture or cerebral disorder. Several cross sectional studies have observed lower bone mineral densities in men with prevalent fracture. ${ }^{90-95}$ In these latter studies, threshold BMD values for fractures seemed to be somewhat higher in men than in women. Men with only non-fragility fractures had no difference in BMD than men without fractures.

In the Hawaii osteoporosis study ${ }^{96}$ a relation was found between low BMD and vertebral fracture risk. Bone density was a significant predictor of vertebral fractures in both men and women. The risk of having a new fracture during follow up increased by 1.5 to 2.0 times for each 1SD decrease in baseline BMD for both women and men, depending on the BMD measurement site. When the incidence of new fractures was examined as a function of calcaneous BMD, men and women had equivalent risks of fracture for a given level of BMD. Similar results were found for the distal and proximal radius BMD measurements. In contrast with $\mathrm{BMD}$, there were substantial differences in fracture risks between men and women at similar levels of bone mineral content (BMC; that is, total bone mineral content in the region of interest; BMD is BMC divided by the projected area of the measurement site). Adjusting for body size reduced the differences between men and women for BMC, with results similar to those for BMD. In the Rotterdam study hip fracture incidence was found to be related to BMD in both women and men. ${ }^{98}$ The relative risk was 2.5 for each SD decrease in femoral neck BMD (1.8-3.6) in women, while this relative risk was 3.0 (1.75.4 ) in men. These relative risks were not statistically different. The relation between baseline BMD and hip fracture risk is similar in 
men and women, while the average BMD is higher in men than in women at every given age, and the decrease of BMD with age is slower in men. For a given absolute hip areal $\mathrm{BMD}$ value, hip fracture risk is similar in both sexes.

The association between changes in BMD and fracture risk was also evaluated in the Hawaii osteoporosis study. ${ }^{97}$ For these analyses, rates of changes in $\mathrm{BMD}$ were calculated up to the end of follow up or the time of the first fracture (whichever came first). Adjusting for bone loss rate did not alter the association between BMD and fracture risk. Changes in $\mathrm{BMC}$ and $\mathrm{BMD}$ were significant predictors of new vertebral fractures after adjusting for bone density, indicating that bone density and bone loss rate both contribute independently to fracture risk. The results indicate that fast decline in bone density is associated with an increased risk of subsequent fractures. Although the magnitude of this effect was comparable for men and women, it did not attain statistical significance for men, possibly because the sample size for men was smaller.

Although the limited data available are not unequivocal, more recent studies seem to indicate that values for the biochemical markers of bone turnover do tend to increase in aging men and that there is a negative association between the level of bone turnover and prevalent bone mineral density in men, as is also the case in women. ${ }^{5062}$ To date there are no published data on the independent contribution of bone turnover on fracture risk in men.

In men with hypogonadism severe deterioration of the parameters of trabecular connectivity was described as the most striking finding. ${ }^{99}$ In 108 men with osteoporosis (62 with vertebral fractures) the correlations between trabecular bone volume and microarchitectural parameters are logarithmic or exponential; after adjustment for age, body mass index and femoral $\mathrm{BMD}$, the risk of vertebral fracture seems to be significantly related to changes of trabecular connectivity. ${ }^{100}$

Johansson and coworkers have reported that prevalent bone mineral density is a predictor of survival both in men and women. ${ }^{101} \mathrm{~A}$ decrease of $1 \mathrm{SD}$ of BMD in a univariate analysis was associated with a 1.39 -fold increase in mortality in both men (95\% CI 1.25 to 1.56$)$ and women (95\% CI 1.22 to 1.58$)$, and a multivariate analysis showed a relative risk of 1.23 (95\% CI 1.10 to 1.41 ) in men and 1.19 (1.02 to 1.39 ) in women. All relations were adjusted for sex, age, and follow up. This study indicates that BMD is a predictor of survival, especially for subjects over 70 ; bone mineral density was found to be a better predictor of imminent death than blood pressure and cholesterol. Similar findings were reported from the Rotterdam study. ${ }^{102}$

\section{Treatment-induced changes in bone density and fracture risk}

At present, no controlled data on the effect of changes in bone mineral density or bone turnover induced by pharmacological intervention, on the resulting fracture rate in men with primary osteoporosis, have been published as a full paper. Preliminary data on a prospective controlled trial of 146 osteoporotic men treated with alendronate and 95 subjects treated with placebo have been reported, ${ }^{103}$ which indicate that increased BMD during antiresorptive treatment is associated with a (non-significant) trend towards reduced risk for vertebral fracture, similar to the findings in women. In a small scale study Ringe et al found an increased vertebral BMD and reduced rate of vertebral fracture during treatment with monofluorophosphate. ${ }^{104}$

In women, large well controlled prospective studies have shown that antiresorptive drugs can effectively reduce fracture risk in osteoporotic patients. ${ }^{105-110}$ Among these trials the observed changes in BMD, reduction of fracture risk, and the relation between them vary, possibly owing to differences in inclusion criteria and measurement technique and/or the pharmacological properties of the drugs. In some of these studies it has been documented that the anti-fracture efficacy is limited essentially to those subjects with initially low bone mass (osteoporotic according to the WHO diagnostic criteria). ${ }^{106}{ }^{111}$ In the Fracture Intervention Trial, larger increases in BMD during alendronate treatment were associated with a lower risk of new vertebral fractures in women with postmenopausal osteoporosis. ${ }^{112}$

Comparison of treatment-induced changes in BMD and fracture rates between these studies in postmenopausal women is hazardous owing to the differences in inclusion criteria. Nevertheless, in a meta-analysis Black et al analysed the results of 13 clinical trials including alendronate, calcitonin, oestradiol, etidronate, raloxifene, risedronate, and tiludronate to determine the extent to which improvement in spine BMD is related to reduction in vertebral fracture incidence. ${ }^{113}$ Trials were included that had at least five incident fractures for each treatment group, lasted for at least two years, and reported changes both in spine BMD and rates of vertebral fractures. Within the range of differences in spine BMD noted in these trials (1 to $8 \%$ ), each $1 \%$ improvement in spine BMD corresponded with a $3.3 \%(95 \%$ CI 1.0 to $5.6 \%$ ) reduction in fracture risk obtained during treatment. Other factors, such as prevalent rate of bone remodelling ${ }^{114}$ or tissue architecture, may also be important. In this regard, it can be mentioned that in studies with antiresorptive drugs increases in BMD are consistently associated with a decreased rate of bone turnover, which in turn can be expected to have favourable effects on the preservation of bone tissue architecture.

\section{Summary and conclusions}

In summary, the at least twofold higher incidence of osteoporotic fractures in women than in men seems to result from quantitative differences in risk factors, rather than from different risk factors (for example, higher BMD, higher BMI, lower rates of falls, etc) Other factors that may contribute to the differences in fracture incidence are the differences in bone geometry with greater bone size in men and the 
more progressive pattern of changes in sex steroid exposure in men than in women. An important factor to be considered is, of course, the shorter life expectancy of men.

Notwithstanding the existing differences in pathophysiology of osteoporosis between sexes and the difference in age-specific incidence of osteoporotic fractures, recent insights also suggest important similarities between osteoporosis in women and men. An important observation in this regard is that, even though there are sex differences in bone geometry, the fracture rate seems to be similar in both sexes for the same absolute areal BMD level. Furthermore, age related rates of BMD changes are similar in elderly men and women, and for both sexes there is a negative relation between bone turnover and prevalent bone mineral density in the elderly.

The main limitation for the extrapolation of treatment outcomes in women to men, is the lack of data on the effects of changes in BMD and bone turnover resulting from pharmacological interventions on fracture rates in men. However, limited information derived from recent trials in primary and glucocorticoidinduced osteoporosis indicates that similar changes in BMD do result in similar trends for changes in fracture rates in both sexes. ${ }^{103} 115116$

The data presented in this review show important points of concordance between both sexes for the relation between BMD and fracture risk in untreated populations. The remaining question is whether it is reasonable to assume that a drug having shown antifracture efficacy in women might also reduce fracture risk in men if similar changes in BMD have been obtained for a similar treatment regimen after two or three years of treatment.

This work was performed on behalf of the Group for the Respect of Ethics and Excellence in Science (GREES). We acknowledge the help and support of Dr Agnusdei (Eli Lilly Europe), Dr A Daifotis (Merck Research Laboratories, USA), Dr D Ethgen (Procter and Gamble Pharmaceuticals, USA), Dr $\mathrm{H}$ Reidel (Novartis Pharma, Germany), Dr A Santora (Merck Research Laboratories, USA), Dr T Sernau (F Hoffman La Roche Ltd, Switzerland), Dr Y Tsouderos (Servier, France). The authors are also indebted to Dr R Balena, Dr M-L The authors are also indebted to Dr R Balena, Dr M-L
Brandi, Dr J Cerny, Dr M Dören, Dr S Gonnelli, Dr M Brandi, Dr J Cerny, Dr M Dören, Dr S Gonnelli, Dr M
Korbonit, Dr F LaRoche, Dr A Lombardi, Dr R Lorenc, Dr C Pouliart, and Dr W Tritthart, who participated in a discussion of this paper and offered valuable comments.

\section{Appendix}

J M Kaufman, Unit for Osteoporosis and Metabolic Bone Diseases, Ghent University Hospital, Ghent, Belgium

O Johnell, Department of Orthopaedics, Malmö General Hospital, Malmö, Sweden

E Abadie, Department Pharmaco Toxico Clinique des Medicaments, Agence Française de Securité des Produits de Santé, Saint-Denis, France

S Adami, Centro Ospedaliero, Clinicizzato di Valeggio, Valeggio, Italy

M Audran, Department of Rheumatology, Centre Hospitalier Universitaire d'Anger, Anger, France

B Avouac, Department of Rheumatology, Hôpital Henri Monda, Creteil, France

W Ben Sedrine, WHO Collaborating Centre for Public Health Aspects of Osteoarticular Disorders, University of Liège, Liège, Belgium

G Calvo, Department of Clinical Pharmacology Hospital de Sant Pau, Universitat Autonoma de Barcelona, Barcelona, Spain

J P Devogelaer, Department of Rheumatology, Cliniques Universitaires St Luc, Brussels, Belgium
V Fuchs, BfArM, Federal Institute for Drugs and Medical Devices, Bonn, Germany

P Nilsson, Medical Products Agency, Uppsala, Sweden

H Pols, Department of Internal Medicine III, Erasmus Universitiy Medical School, Rotterdam, The Netherlands

J Ringe, Department of Internal Medicine IV, Klinikum Leverkusen, Leverkusen, Germany

L Van Haelst, Departments of Endocrinology and Pharmacology, Vrije Universiteit Brussels, Brussels, Belgium

J Y Reginster for the Group for the Respect of Ethics and Excellence in Medicine, WHO Collaborating Centre for Public Health Aspects of Osteoarticular Disorders, University of Liège, Liège, Belgium

1 Jackson JA, Kleerekoper M. Osteoporosis in men diagnosis, pathophysiology, and prevention. Medicine (Baltimore) 1990;69:137-52.

2 Scane AC, Sutcliffe AM, Francis DM. Osteoporosis in men. Baillieres Clin Rheumatol 1993;7:589-601.

3 Orwoll ES, Klein RF. Osteoporosis in men. Endocr Rev 1995;16:87-115.

4 Seeman E. Osteoporosis in men. Baillieres Clin Rheumatol 1997;11:613-29.

5 Hofman A, Grobber DE, de Jong PT, van den Ouweland FA. Determinants of disease and disability in the elderly: the Rotterdam elderly study. Eur J Epidemiol 1991;7:403-22.

6 Jonsson B, Begner U, Redlund-Johnell I, Johnell O. Forearm fractures in Malmö, Sweden. Changes in the incidence occurring during the 1950s, 1980s and 1990s. Acta Orthop Scand 1999;70:129-32.

7 Jones G, Nguyen T, Sambrook PN, Kelly PJ, Gilbert C, Eisman J. Symptomatic fracture incidence in elderly men and women : the Dubbo Osteoporosis Epidemiology Study (DOES). Osteoporos Int 1994;4:277-82.

8 De Laet C, van Hout BA, Burger H, Hofman A, Pols HAP. Bone density and risk of hip fracture in men and women: cross sectional analysis. BMJ 1997;315:221-5.

9 De Laet C. Osteoporosis and fracture prevention: costs and effects modeled on the Rotterdam study. (Thesis 1999.)

10 Boereboom FTJ, Raymakers JA, de Groot RRM, Duursma SA. Epidemiology of hip fractures in the Netherlands: SA. Epidemiology of hip fractures in the Netherlands:
women compared with men. Osteoporosis Int 1992;2:279284 .

11 Nydegger V, Rizzoli R, Rapin CH, Vasey H, Bonjour JPh. Epidemiology of fractures of the proximal femur in Geneva: incidence, clinical and social aspects. Osteoporos Int 1991;2:42-7.

12 Maggi S, Kelsey JL, Litvak J, Heyse SP. Incidence of hip fractures in the elderly: a cross-national analysis. Osteoporosis Int 1991;1:232-41.

13 Kannus P, Niemi S, Parkkari J, Palvanen M, Vuori I, Järvinen M. Hip fractures in Finland between 1970 and 1997 and predictions for the future. Lancet 1999;353. 802-5.

14 Diez A, Puig J, Martinez MT, Diez JL, Aubia J, Vivancos J. Epidemiology of fractures of the proximal femur associated with osteoporosis in Barcelona, Spain. Calcif Tissue Int 1989;44:382-6.

15 Rogmark C, Sernbo I, Johnell O, Nilsson JA. Incidence of hip fractures in Malmö, Sweden, 1992-1995. Acta Orthop Scand 1999;70:19-22.

16 Falch JA, Kaastad TS, Bøhler G, Espeland J, Sundsvold OJ. Secular increase and geographical differences in hip fracture incidence in Norway. Bone 1993;14:643-5.

7 Muscat Baron Y, Brincat M, Galea R, Muscat Baron A. The epidemiology of osteoporotic fractures in a mediterranean country. Calcif Tissue Int 1994;54:365-9.

18 Johnell O, Nilsson BE, Obrant KJ, Sernbo I. Age and sex pattern of hip fracture-changes in 30 years. Acta Orthop Scand 1984;55:290-2.

19 Melton LJ III, Kan SH, Wahner HW, Riggs BI. Lifetime fracture risk: an approach to hip fracture risk assessment based on bone mineral and age. J Clin Epidemiol 1988;41: 985-94.

20 Oden A, Dawson A, Dere W, Johnell O, Jonsson B, Kanis JA. Lifetime risk of hip fractures is underestimated. Osteoporos Int 1998;8:599-603.

21 a. Cooper C, Campion G, Melton III LJ. Hip fractures in the elderly: a world-wide projection. Osteoporos Int 1992; 2:285-9. b. Cooper C, Atkinson EJ, O'Fallon WM, Melton III LJ. Incidence of clinically diagnosed vertebral fractures: a population-based study in Rochester, Minnesota, 19851989. J Bone Miner Res 1992;7:221-7.

22 Gullberg B, Johnell O, Kanis J. World-wide projections for hip fracture. Osteoporos Int 1997;7:407-13.

23 Bengnér U, Johnell O, Redlund-Johnell I. Changes in incidence and prevalence of vertebral fractures during 30 years. Calcif Tissue Int 1988;42:293-6.

24 O'Neill TW, Felsenberg D, Varlow J, Cooper C, Kanis JA, Silman AJ, et al. The prevalence of vertebral deformity in European men and women: the European Vertebral Osteoporosis Study. J Bone Miner Res 1996;11:1010-18.

25 Burger H, Van Daele PLA, Grashuis K, Hofman A, Burger H, Van Daele PLA, Grashuis K, Hofman A,
Grobbee DE, Schütte HE, et al. Vertebral deformities and functional impairment in men and women. J Bone Miner Res 1997;12:152-7. 
26 Felsenberg D, Lunt M, Armbrecht G, Benevolenskaya L, Bhalla A, Armas JB, et al. Rates and determinants of vertebral fracture incidence in European men and
Bone Miner Res 1999;14(suppl 1):S159:1105,

27 Jones G, Nguyen T, Sambrook P, Kelly PJ, Eisman JA. Progressive loss of bone in the femoral neck in elderly people: longitudinal findings from the Dubbo osteoporosis epidemiology study. BMJ 1994;309:691-5.

28 Johnell O. Fracture outcomes: consequences of osteoporosis for individuals and society. Proceedings Fourth International Symposium on Osteoporosis. 1993;67-9.

29 Sernbo I, Johnell O. Consequences of a hip fracture: a prospective study over 1 year. Osteoporos Int 1993;3:148-53.

30 Cooper C, Atkinson EJ, Jacobsen SJ, O'Fallon WM, Melton III LJ. Population-based study of survival after osteoporotic fractures. Am J Epidemiol 1993;137:1001-5.

31 Center JR, Nguyen TV, Schneider D, Sambrook PN, Eisman JA. Mortality after all major types of osteoporotic fracture in men and women: an observational study. Lancet 1999;353:878-82.

32 Lips P, Cooper C, Agnusdei D, Caulin F, Egger P, Johnell O, et al. Quality of life as outcome in the treatment of osteoporosis: the development of a questionnaire for quality of life by the European Foundation for Osteoporosis. Osteoporos Int 1997;7:36-8.

33 Lips P, Cooper C, Agnusdei D, Caulin F, Egger P, Johnell O, et al. Quality of life in patients with vertebral fractures: validation of the quality of life questionnaire of the European Foundation for Osteoporosis (QUALEFFO). Osteoporos Int 1999;10:150-60.

34 Matthis C, Raspe H, EVOS-Gruppe in Deutschland. Krankheitslast bei vertebralen deformitäten. Med Klin 1998;93(suppl II):41-6.

35 Reginster JY, Gillet P, Sedrine WB, Brands G, Ethgen O, de Froidmont $\mathrm{C}$, et al. Direct costs of hip fractures in patients over 60 years of age in Belgium. Pharmacoeconomics over 60 years of

36 Nguyen TV, Eisman JA, Kelly PJ, Sambrook PN. Risk factors for osteoporotic fractures in elderly men. Am J Epidemiol 1996;144:255-62.

37 Nyquist F, Gardsell P, Sernbo I, Jeppsson JO, Johnell O. Assessment of sex hormones and bone mineral density in relation to occurrence of fracture in men: a prospective population-based study. Bone 1998;22:147-51.

38 Mussolino ME, Looker AC, Madans JH, Langlois JA, Orwoll ES. Risk factors for hip fracture in white men: the NHANES I epidemiologic follow-up study. J Bone Miner Res 1998;13:918-24.7

39 Poor G, Atkinson EJ, O'Fallon WM, Melton III LJ. Predictors of hip fractures in elderly men. J Bone Miner Res 1995; 10:1900-7.

40 Grisso JA, Kelsey JL, O’Brien LA, Miles CG, Sidney S, Maislin G, et al. Risk factors for hip fracture in men. Hip Fracture Study Group. Am J Epidemiol 1997;145:786-93.

41 Fujiwara S, Kasagi F, Yamada M, Kodama K. Risk factors for hip fracture in a Japanese cohort. J Bone Miner Res 1997;12:998-1004.

42 Hoidrup S, Gronbaek M, Gottschau A, Lauritzen JM, Schroll M. Alcohol intake, beverage preference, and risk of hip fracture in men and women. Am J Epidemio 1999;149:993-1001.

43 Kanis J, Johnell O, Gullberg B, Allander E, Elffors L, Ranstam $\mathrm{J}$, et al. Risk factors for hip fracture in men from Southern Europe: the MEDOS study. Osteoporos Int 1999;9:45-54.

44 Johnell O, Gullberg B, Kanis JA, Allander E, Elffors L, Dequeker J, et al. Risk factors of hip fracture in European women. J Bone Miner Res 1995;10:1802-15.

45 Stanley HL, Schmitt BP, Poses RM, Deiss WP. Does hypogonadism contribute to the occurrence of a minimal hypogonadism contribute to the occurrence of a minimal 1991;39:766-71.

46 Jackson JA, Riggs M, Spiekerman AM. Testosterone deficiency as a risk factor for hip fractures in men: a casecontrol study. Am J Med Sci 1992;304:4-8.

47 Boonen S, Vanderschueren D, Cheng XG, Verbeke G Dequeker J, Geusens P, et al. Age-related (type II) femora neck osteoporosis in men: biochemical evidence for both hypovitaminosis D- and androgen deficiency-induced bone resorption. J Bone Miner Res 1997;12:2119-26.

48 Orwoll ES, Meier DE. Alterations in calcium, vitamin D, and parathyroid hormone physiology in normal men with aging: relationship to the development of senile osteopenia J Clin Endocrinol Metab 1986;63:1262-9.

49 Riggs BL, Melton LJ III. Medical progress: involutional osteoporosis. N Engl J Med 1986;314:1676-86.

50 Gallagher JC, Kinyamu HK, Fowler SE, Dawson-Hughes B, Dalsky GP, Sherman SS. Calciotropic hormones and bone markers in the elderly. J Bone Miner Res 1998;13:475-82.

51 Eastell R, Boyle IT, Compston J, Cooper C, Fogelman I, Francis RM, et al. Management of male osteoporosis: report of the UK Consensus Group. Q J Med 1998;91:71-92.

52 Langdahl BL, Ralston SH, Grant SF, Eriksen EF. An Sp1 binding site polymorphism in the COLIA1 gene predicts osteoporotic fractures in both men and women. J Bone Miner Res 1998;13:1384-9.

53 Stepan JJ, Lachman M, Zverina J, Pacovsky V, Baylink DJ. Castrated men exhibit bone loss: effect of calcitonin treatment on biochemical indices of bone remodeling. J Clin Endocrinol Metab 1989;69:523-7.

54 Goldray D, Weisman Y, Jaccard N, Merdler C, Chen J, Matzkin H. Decreased bone density in elderly men treated with the gonadotropin-releasing hormone agonist decapeptyl (D-Trp ${ }^{6}$-GnRH). J Clin Endocrinol Metab 1993;76: peptyl (D-1 $288-90$.
55 Vermeulen A. Androgens in the aging male. J Clin Endocrinol Metab 1991;73:221-4.

56 Kaufman JM, Vermeulen A. Declining gonadal function in elderly men. Baillieres Clin Endocrinol Metab 1997;11: 289-309.

57 Ferrini R, Barret-Connor. Sex hormones and age: a cross-sectional study of testosterone and estradiol and their bioavailable fractions in community-dwelling men. Am J Epidemiol 1998;147:750-4.

58 Kaufman JM. Androgens, bone metabolism and osteoporosis. In: Oddens J, Vermeulen A, eds. Androgens and the aging male. New York: The Partenon Publishing Group, 1996:39-60.

59 Clarke BL, Ebeling PR, Jones JD, Wahner HW, O'Fallon WM, Riggs $\mathrm{BL}$, et al. Changes in quantitative bone histomorphometry in aging healthy men. J Clin Endocrinol Metab 1996;81:2264-70.

60 Murphy S, Khaw K, Cassidy A, Compston JE. Sex hormones and bone mineral density in elderly men. Bone and Mineral 1993;20:133-40.

61 Greendale GA, Edelstein S, Barrett-Connor E. Endogenous sex steroids and bone mineral density in older women and men: the Rancho Bernardo Study. J Bone Miner Res 1997; 12:1833-43.

62 Khosla S, Melton III LJ, Atkinson EJ, O'Fallon WM, Klee GG, Riggs BL. Relationship of serum sex steroid levels and bone turnover markers with bone mineral density in men and women: a key role for bioavailable estrogen. J Clin Endocrinol Metab 1998;83:2266-74.

63 Ettinger B, Pressman A, Sklarin P, Bauer DC, Cauley JA, Cummings SR. Associations between low levels of serum estradiol, bone density, and fractures among elderly women: the study of osteoporotic fractures. J Clin Endocrinol Metab 1998;83:2239-43.

64 Slemenda CW, Longcope C, Zhou L, Hui SL, Peacock M, Johnston CC. Sex steroids and bone mass in older men. Positive associations with serum estrogens and negative association

65 Gillberg P, Johansson AG, Ljunghall S. Decreased estradiol levels and free androgen index and elevated sex hormonebinding globulin levels in male idiopathic osteoporosis. balcif Tissue Int 1999;64:209-13.

66 Smith EP, Boyd J, Frank GR, Williams TC, Lubahn DB, Korach KS. Estrogen resistance caused by a mutation in the estrogen-receptor gene in a man. N Engl J Med 1994; 331:1056-61

67 Bilezikian JP, Morishima A, Bell J, Grumbach MM. Increased bone mass as a result of estrogen therapy in a man with aromatase deficiency. N Engl J Med 1998;339: 599-603.

68 Riggs BL, Khosla S, Melton III LJ. A unitary model for involutional osteoporosis: estrogen deficiency causes both type I and type II osteoporosis in postmenopausal women and contributes to bone loss in aging men. J Bone Miner Res 1998;13:763-73.

69 Katznelson L, Finkelstein JS, Schoenfeld DA, Rosenthal DI, Anderson EJ, Klibanski A. Increase in bone density and lean body mass during testosterone administration in men with acquired hypogonadism. J Clin Endocrinol Metab 1996;81:4358-65.

70 Behre HM, Kliesch S, Leifke E, Link TM, Nieschlag E. Long-term effect of testosterone therapy on bone mineral density in hypogo

71 Tenover J. Abstracts of the $80^{\text {th }}$ Annual Meeting of the Endocrine Society, Bethesda MD: Endocrine Society, 1998

72 Snyder P, Peachey H, Hannoush P, Berlin JA, Loh L, Holmes $\mathrm{JH}$, et al. Effect of testosterone treatment on bone mineral density in men over 65 years of age. J Clin Endocrinol Metab 1999;84:1966-72.

73 Kenny AM, Preswood KM, Marcello KD, Foll PM, Raisz LG. The effect of transdermal testosterone on bone mineral density (BMD), bone turnover markers and muscle strength in older men [abstract]. J Bone Miner Res 1999;14(suppl):S184.

74 Mazess RB, Barden HS, Drinka PJ, Bauwens SF, Orwoll ES, Bell NH. Influence of age and body weight on spine and femur bone mineral density in US white men. J Bone Miner Res 1990;5:645-52.

75 Orwoll ES, Oviatt SK, McClung MR, Deftos LJ, Sexton G. The rate of bone mineral loss in normal men and the effects of calcium and cholecalciferol supplementation. Ann Intern Med 1990;112:29-34.

76 Davis JW, Ross PD, Vogel JM, Wasnick RD. Age-related changes in bone mass among Japanese-American men. Bone and Mineral 1991;15:227-36.

77 Tobin JD, Fox KM, Cejku MI. Bone density changes in normal men: a 4-19 year longitudinal study. J Bone Miner Res 1993;8:102.

78 Slemenda CW, Christian JC, Reed T, Reister TK, Williams CJ, Johnston CC. Long-term bone loss in men: effects of genetic and environmental factors. Ann Intern Med 1992; 117:286-91

79 Hannan MT, Felson DT, Anderson JJ. Bone mineral density in elderly men and women : results from the Framingham Osteoporosis Study. J Bone Miner Res 1992; 7:547-53.

80 Riggs BL, Wahner HW, Dunn WL, Mazess RB, Offord KP, Melton LJI. Differential changes in bone mineral density of the appendicular and axial skeleton with aging. J Clin Invest 1981;67:328-35. 
81 Burger $\mathrm{H}$, de Laet CEDH, van Daele PLA, Weel AEAM, Witteman JCM, Hofman A, et al. Risk factors for increased
bone loss in an elderly population. The Rotterdam study. bone loss in an elderly population.

82 Mosekilde L, Mosekilde L. Sex differences in age-related changes in vertebral body size, density and biomechanical competence in normal individuals. Bone 1990;11:67-73.

83 Beck TJ, Ruff CB, Scott Jr WW, Plato CC, Tobin JD, Quan CA. Sex differences in geometry of the femoral neck with aging: a structural analysis of bone mineral data. Calcif Tissue Int 1992;50:24-9.

84 Garn SM, Sullivan TV, Decker SA, Larkin FA, Hawthorne VM. Continuing bone expansion and increasing bone loss over a two-decade period in men and women from a total community sample. Am J Hum Biol 1992;4:57-67.

85 Gilsanz V, Boechat MI, Gilsanz R, Loro ML, Roe TF, Goodman WG. Gender differences in vertebral sizes in adults: biomechanical implications. Radiology 1994;190: 678-82.

86 Ebbesen EN, Thomsen JS, Beck-Nielsen H, NepperRasmussen HJ, Mosekilde L. Vertebral bone density evaluated by dual-energy X-ray absorptiometry and quantita

87 World Health Organization. Assessment of fracture risk and its application to screening for postmenopausal osteoporosis. WHO: Geneva, Switzerland, 1994. (Technical report series No 843.)

88 Looker AC, Orwoll ES, Johnston CC, Lindsay RL, Wahne HW, Dunn WL, et al. Prevalence of low femoral density in older US adults from NHANES III. J Bone Miner Res 1997;12:1761-8

89 Gärdsell P, Johnell $\mathrm{O}$, Nilsson $\mathrm{BE}$. The predictive value of forearm bone mineral content measurements in men. Bone 1990;11:229-32

90 Melton LJ III, Atkinson EJ, O'Connor MK, O'Fallon WM, Riggs BL. Bone density and fracture risk in men. J Bone Miner Res 1998;13:1915-23.

91 Riggs BL, Wahner HW, Seeman E, Offord KP, Dunn WL, Mazess R, et al. Changes in bone mineral density of the Mazess $\mathrm{R}$, et al. Changes in bone mineral density of the 1982;70:716-23.

92 Mann T, Oviatt SK, Wilson D, Nelson D, Orwoll ES. Vertebral deformity in men. J Bone Miner Res 1992;7:1259-65.

93 Chevalley T, Rizzoli R, Nydegger V, Slosman D, Tkatch L, Rapin C, et al. Preferential low bone mineral density of the femoral neck in patients with a recent fracture of the proximal femur. Osteoporos Int 1991;1:147-54.

94 Karlsson MK, Johnell O, Nilsson BE, Sernbo I, Obrant KJ. Bone mineral mass in hip fracture patients. Bone 1993;14: $161-5$

95 Legrand E, Chappard D, Pascaretti C, Duquenne M, Rondeau C, Simon Y, et al. Bone mineral density and vertebral fractures in men. Osteoporos Int 1999;10:265-70.

96 Heilbrun LK, Ross PD, Wasnich RD, Yano K, Vogel J. Characteristics of respondents and nonrespondents in a prospective study of osteoporosis. J Clin Epidemiol 1991; 44:233-9.

97 Ross PD, Lombardi A, Freedholm D. The assessment of bone mass in men. In: Orwoll E, ed. Osteoporosis in men. bone mass in men. In: Orwoll E, ed. Osteof

98 De Laet C, van Hout BA, Burger H, Weel AEAM, Hofman A, Pols HAP. Hip fracture prediction in elderly men and women: validation in the

99 Legrand E, Chappard D, Pascaretti Ch, Audran M. Is trabecular bone micro-architecture conditioned by etiology in male osteoporosis [abstract]? J Bone Miner Res 1997;12(suppl 1):S369.

100 Legrand E, Chappard D, Pascaretti Ch, Duquenne M, Krebs S, Rohmer, et al. Trabecular bone microarchitecture, bone mineral density and vertebral fractures in male osteoporosis. J Bone Miner Res 2000;15:13-19.

101 Johansson C, Black D, Johnell O, Odén A, Mellström D. Bone mineral density is a predictor of survival. Calcif Tissue Int 1998;63:190-6.
102 van der Klift M, Geleijnse JM, van der Kuip AM, Hofman A, Pols HAP. Bone mineral density as a risk-indicator for mortality in the elderly men and women: the Rotterdam study [abstract]. J Bone Miner Res 1999;14(suppl 1): S509:SU309.

103 Orwoll E, Ettinger M, Weiss S, Miller P, Kendler D, Graham J, et al. Alendronate treatment of osteoporosis in men [abstract]. J Bone Miner Res 1999;14(suppl 1):S184.

104 Ringe JD, Dorst A, Kipshoven C, Rovati LC, Setnikar I. Avoidance of vertebral fractures in men with idiopathic osteoporosis by a three year therapy with calcium and lowdose intermittent monofluorophosphate. Osteoporos Int $1998 ; 8: 47-52$.

105 Black DM, Cummings SR, Karpf DB, Cauley JA, Thompson DE, Nevitt MC, et al. Randomised trial of effect of alendronate on risk of fracture in women with existing vertebral fractures. Lancet 1996;348:1535-41.

106 Cummings SR, Black DM, Thompson DE, Applegate WB, Barrett-Connor E, Musliner TA, et al. Effect of alendronate on risk of fracture in women with low bone density but without vertebral fractures: results from the fracture intervention trial. JAMA 1998;280:2077-82.

107 Ettinger B, Black D, Mitlak B, Knickerbocker RK, Nickelsen T, Genant HK, et al. Reduction of vertebral fracture risk in postmenopausal women with osteoporosis treated with raloxifene: results from a 3-year randomized clinical trial. JAMA 1999;282:637-45.

108 Watts NB, Hangartner T, Chesnut C, Genant HK, Miller $\mathrm{PD}$, Eriksen EF, et al. Risedronate reduces osteoporotic fractures in postmenopausal women. $81^{\text {st }}$ Annual Meeting of the Endocrine Society, Program and Abstracts. Bethesda MD: Endocrine Society, 1999;442:abstract P3-15.

109 Silverman SL, Moniz C, Andriano K, Block J, Chesnut C, Doyle $\mathrm{D}$, et al. Salmon calcitonin nasal spray prevents vertebral fractures in established osteoporosis. Final world wide results of the "PROOF" study [abstract]. Calcif Tiss Int 1999;64(suppl 1):O-26.

110 Harris ST, Watts NB, Genant HK, McKeever CD, Hangartner T, Keller M, et al. Effects of risedronate treatment on vertebral and nonvertebral fractures in women with postmenopausal osteoporosis. A randomized controlled trial. JAMA 1999;282:1344-52.

111 Miller P, Roux C, McClung M, Adami S, Eastell R, Pack S, et al. Risedronate reduces hip fractures in patients with low femoral neck bone mineral density[abstract]. Arthritis Rheum 1999;42(suppl):9.

112 Hochberg MC, Ross PD, Black D, Cummings SR, Genant HK, Nevitt Mc, et al for the Fracture Intervention Trial Study Group. Larger increases in bone mineral density during alendronate therapy are associated with a lower risk of new vertebral fractures in women with postmenopausal osteoporosis [abstract]. Arthritis Rheum 1999;42(suppl): S289.

113 Black DM, Pearson J, Harris F, LaCroix A, Cummings SR. Predicting the effect of antiresorptive treatments on risk of vertebral fractures: a meta-analysis [abstract]. J Bone Miner Res 1999;14(suppl 1):S137.

114 Bjarnason NH, Christiansen C, Sarkar S, Mitlak B, Knickerbocker R, Delmas P, et al for the MORE study group. Six months changes in biochemical markers predict 3-year response in vertebral fracture rate in postmenopausal, osteoporotic women: results from the MORE study [abstract]. oporotic women: results from the MORE stud

115 Saag KG, Emkey R, Schnitzer TJ, Brown JP, Hawkins F, Goemaere S, et al. Alendronate for the prevention and treatment of glucocorticoid-induced osteoporosis. N Engl J Med 1998;339:292-9.

116 Adachi JD, Bensen WG, Brown J, Hanley D, Hodsman A, Josse $\mathrm{R}$, et al. Intermittent etidronate therapy to prevent corticosteroid-induced osteoporosis. N Engl J Med 1997; $337: 382-7$. 